Sisters of Salome 
ALSO BY TONI BENTLEY

Winter Season: A Dancer's Journal

Holding On to the Air: An Autobiography,

by Suzanne Farrell with Toni Bentley

Costumes by Karinoka 

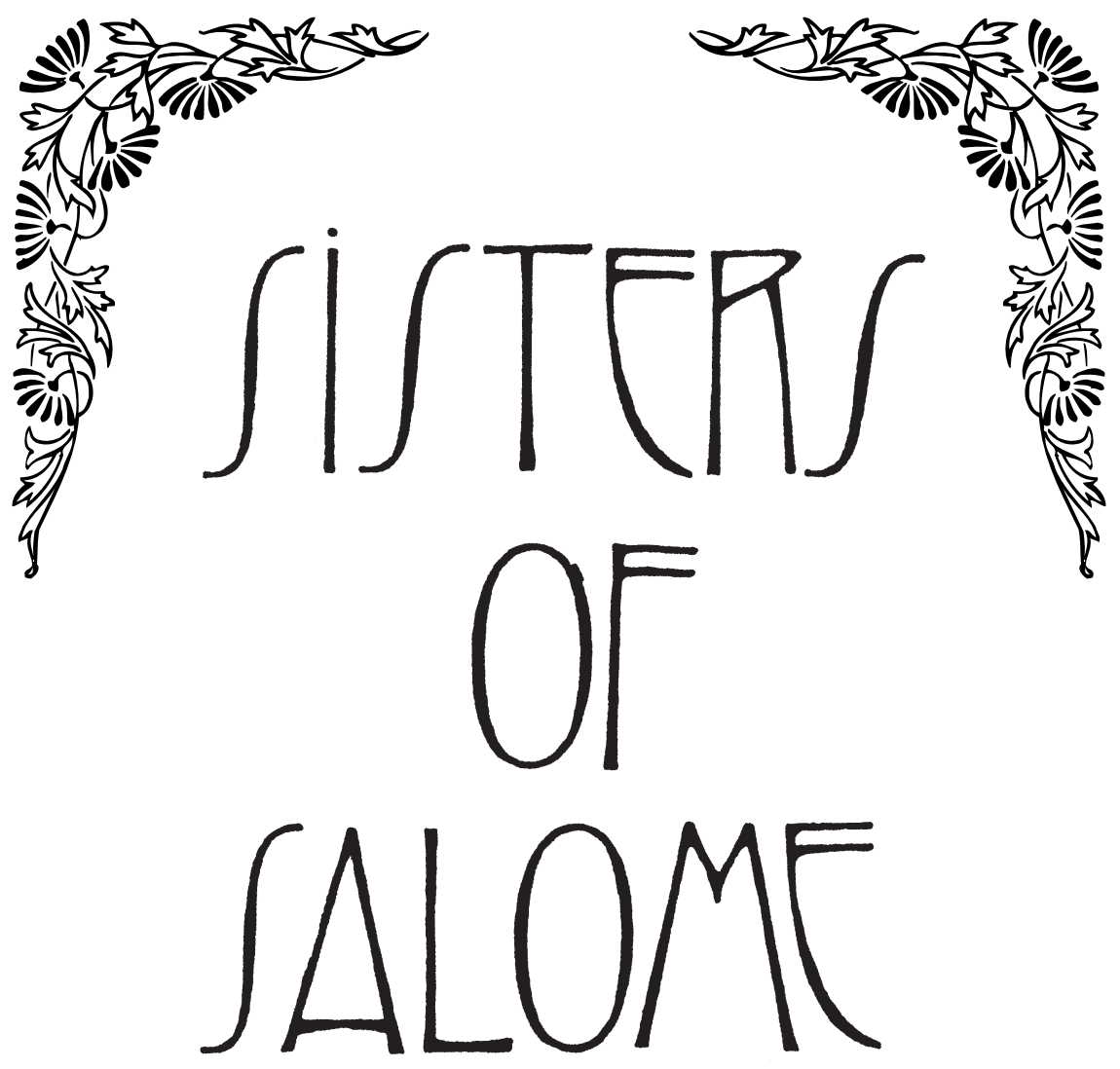

\section{Toni Bentley}

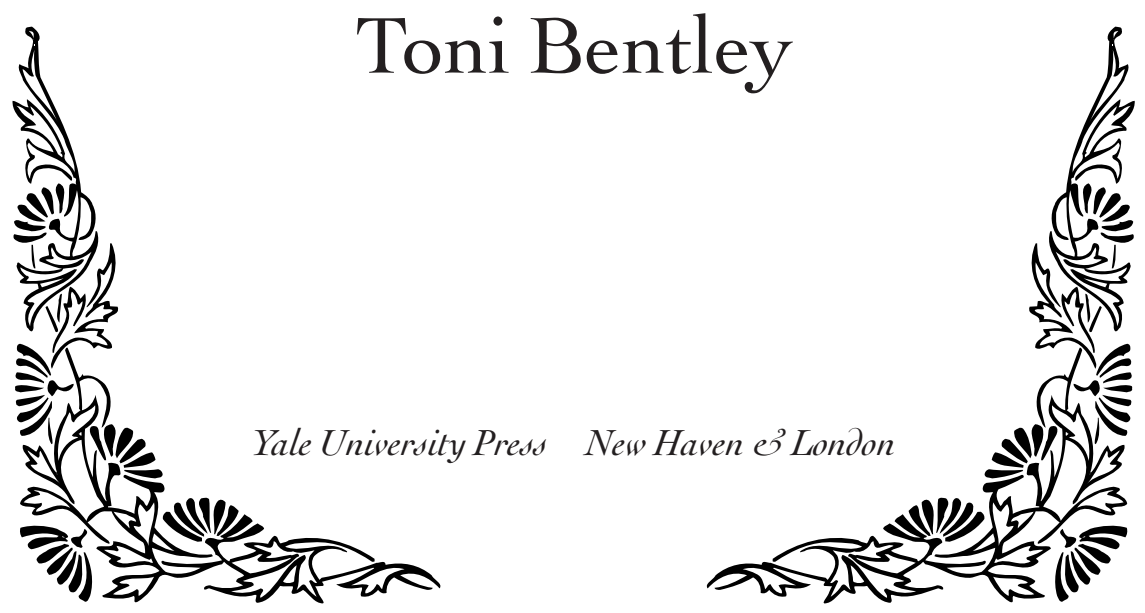


Copyright (C) 2002 by Toni Bentley.

All rights reserved.

This book may not be reproduced, in whole or in part, including illustrations, in any form (beyond that copying permitted by Sections I07 and 108 of the U.S. Copyright Law and except by reviewers for the public press), without written permission from the publishers.

"Light as a Breeze," by Leonard Cohen, Copyright (C 1992 Sony/ATV Songs LLC. All rights administered by Sony/ATV Music Publishing, 8 Music Square West, Nashville, $\mathrm{TN}_{37203}$. All rights reserved. Used by permission.

"Waiting for the Miracle," by Leonard Cohen, Copyright (C) 1992 Sony/ATV Songs LLC, Robinhill Music, Universal-MCA Music Publishing and Geffen Music. All rights on behalf of Sony/ATV Songs LLC administered by Sony/ATV Music Publishing, 8 Music Square West, Nashville, TN 37203. All rights reserved. Used by permission.

Designed by James J. Johnson and set in Cochin Roman types by The Composing Room of Michigan, Inc., Grand Rapids, Michigan. Printed in the United States of America by R. R. Donnelley and Sons, Harrisonburg, Virginia.

\section{Library of Congress Cataloging-in-Publication Data}

Bentley, Toni.

Sisters of Salome / Toni Bentley.

$$
\text { p. } \mathrm{cm} \text {. }
$$

Includes bibliographical references (p. ) and index.

ISBN o-300-09039-० (alk. paper)

I. Women dancers - Biography. 2. Feminism and dance. 3. Salome (Biblical figure) I. Title.

$\mathrm{GV}_{\mathrm{I} 785}$. A $\mathrm{B}_{47} 2002$

$792.8^{\prime} \circ 92^{\prime} 2-\mathrm{dc} 2 \mathrm{I}$

2001005243

A catalogue record for this book is available from the British Library.

The paper in this book meets the guidelines for permanence and durability of the Committee on Production Guidelines for Book Longevity of the Council on Library Resources. 
For L.K. 


\section{The Dance?}

Believe what you care to.

Picture it any way you want to.

All the world knows truth is best revealed

by gradual deception.

It was a striptease pure and simple.

- George Garrett, "Salome" (1963)

The significance of the femme fatale lies not in her gender but in her freedom.

-Angela Carter, Shaking a Leg: Collected Writings (1998) 